\title{
Chapter 13 \\ Structured Film-Viewing Preferences \\ and Practices: A Quantitative Analysis \\ of Hierarchies in Screen and Content \\ Selection Among Young People \\ in Flanders
}

\author{
Aleit Veenstra, Philippe Meers, and Daniël Biltereyst
}

\subsection{Introduction}

A prominent voice in the analyses of contemporary audiences and their film-watching preferences is Jenkins (2006), who focuses on audience agency. In his work, Jenkins argues that contemporary media audiences live in an era of "convergence culture," which refers to "the flow of content across multiple media platforms, the cooperation between multiple media industries, and the migratory behavior of media audiences who will go almost anywhere in search of the kinds of media experiences they want" (Jenkins 2006: 2). In his view, audiences are deemed (inter)active in their choice of technology, screen and media products, and active audiences do not necessarily oppose mainstream culture. In his more recent work, Jenkins (Jenkins et al. 2013, 2016) echoes this focus on audience agency, wherein power of participation lies in the interaction between audiences, media products and media industries.

In contrast, a growing group of scholars stresses that by merely emphasizing audience agency through individual choice, the understanding of structural constraints in media consumption fades. One important body of the literature, often linked to a critical political economy perspective on audiences (Biltereyst and Meers 2011), argues that audiences perform free labor by engaging with the media products presented to them (e.g., Moisander et al. 2013), that convergence culture is used to justify reorganization leading to budget cuts and increase workload (e.g., Edge 2011) or that this

\footnotetext{
A. Veenstra $(\bowtie) \cdot$ P. Meers

University of Antwerp, Stadscampus, Sint-Jacobsstraat 2, 2000 Antwerpen, Belgium

e-mail: aleit.veenstra@uantwerpen.be

P. Meers

e-mail: philippe.meers@uantwerpen.be

D. Biltereyst

Ghent University, Campus Aula, Universiteitstraat 4, 9000 Gent, Belgium

e-mail: daniel.biltereyst@ugent.be

(C) The Author(s) 2020

P. Szczepanik et al. (eds.), Digital Peripheries, Springer Series in Media Industries, https://doi.org/10.1007/978-3-030-44850-9_13
} 
perspective points to the limitations on the audience's choice and access by different kinds of financial or other barriers set by media industry strategies (e.g., Bird 2011; Kim 2012; Holt and Sanson 2014).

These critiques rightly point to the continuation of existing structures in media consumption, but rarely directly address audiences - a critique that also applies to Jenkins' (2006) analysis of specialized audience participation. As Couldry argues, the "only plausible way to understand the politics of convergence is to develop a better sociological and cultural analysis of what people are doing with and around media" (Couldry 2011: 498). Biltereyst and Meers (2011) underline the usefulness of studying audiences to understanding the politics of media-a research tradition not often associated with the study of audiences. They argue that political economy can simultaneously provide an important contextualization as well as a better understanding of the audience's composition, preferences and practices.

This chapter combines the approaches of Biltereyst and Meers (2011) and Couldry (2011) to studying audiences. We present a sociological analysis of the hierarchies that structure the feature film-watching practices and preferences of a large representative sample of audiences aged 16-18 living in Flanders (the northern Dutchspeaking region of Belgium). This is a demographic that enjoys watching movies on a regular basis (BFI 2015) and that adapts easily to new technologies such as new screens (Bennett and Robards 2014). In other words, if we want to find migratory audiences, the most likely place is among youngsters. Our analysis focuses on two traditional hierarchies in watching feature films: the country of production (or origin) and screen size. In analyzing these both as separate and related consumption preferences and practices, we anchor our understanding in a local audience, living in a specific region. Small nations may be limited in film budgets and number of productions, but advantages such as local anchorage, cultural specificity and similarity in potential audiences also apply (Hjort and Petrie 2007). ${ }^{1}$ In this chapter, we focus upon the Flemish part of the country: With 6.2 million people living on $13.522 \mathrm{~km}^{2}$ (Belgian Federal Government 2017), Flanders has an independent film policy. As such, it fits the definition of small nation cinema as used by Hjort and Petrie (2007). ${ }^{2}$

Previous research on young people in Flanders indicates that Hollywood is most popular and most appreciated, next to British cinema. European (i.e., mainly French, Italian, German and Spanish cinema) film lacks popularity and appreciation, while Flemish film is indeed frequently watched and somewhat appreciated (Meers 2002,

\footnotetext{
${ }^{1}$ The concept of national film can be problematic for multilingual/multicultural countries such as Belgium, where three linguistically different film audience communities coexist and where local governments support film production in local languages (Willems 2010).

${ }^{2}$ The country has three official languages: Dutch (spoken in Flanders and Brussels), French (spoken in Wallonia and Brussels) and German (spoken by a very small portion of the population living in the southeast). For Flanders, for instance, there is a government-funded body that has supported Flemish film production since 2002: Vlaams Audiovisueel Fonds (VAF, Flemish Audiovisual Fund). The fund aims to provide financial support, support further professionalization in audiovisual industries and assist with international exposure (Vlaams Audiovisueel Fonds 2016). The recent successive Academy Award nominations for the Flemish films The Broken Circle Breakdown (2012) and Rundskop (2011) are often cited as proof of a successful policy.
} 
2004). In analyzing the extent to which these hierarchies between film origins remain valid and how they relate to screen use-e.g., is Hollywood still the only film to watch in the cinema and is Flemish film still associated with television viewing-we can identify structures in which contemporary media consumption takes place.

\subsection{Hierarchies in Origin: Hollywood Film, European Film and National Film}

The differentiation in film origin, which we understand as the country of production, is as old as the medium itself, with a long tradition of a conflictual relationship between Europe and the USA (Higson and Maltby 1999; Decherney 2013). Whereas European cinema has often been referred to as a cultural and economic patchwork quilt, Hollywood became a "metonym for the well-organised [sic] and substantially capitalized American film industry, with its international market hegemony" (Higson and Maltby 1999: 2). Hollywood's hegemony is strongly associated with a long tradition of worldwide-consumed blockbusters, with Hall (2002) even arguing that Hollywood is synonymous with blockbusters. Cucco (2009) voices a more nuanced stance in claiming that Hollywood exists beyond its most popular films, yet is best represented by these blockbusters. In addition, the profitable demographic of teens is specifically targeted by themes that appeal to them (Hay and Bailey 2002; Maltby 1999).

Hollywood thus dominates the global film market through blockbuster hits, while displaying a remarkable durability in the monopolization of international markets (Miller et al. 2001). As Scott concludes, Hollywood "is a central point of reference in the cultural economy of the modern world" (Scott 2005: 175). The resulting hegemony leads to a uniform filmic language (Elsaesser 2012) with a "narrative transparency" that characterizes Hollywood film as the most successful way of making film (Olsen 1999). While most authors recognize Hollywood's dominance, only a few speak of a continuing increase in the homogenization of film consumption. Fu and Govindaraju are two such voices in concluding that between 2002 and 2007, "the cinema markets have selected and consumed individual Hollywood movies in ways that are increasingly homogeneous" (Fu and Govindaraju 2010: 232). In a later article, Fu (2012) nuances his argument on Hollywood's market penetration, stating that Hollywood is most appreciated in countries that display a close cultural proximity to the USA (as measured through an understanding of English).

Concerns over homogenization (or unambiguous preference for Hollywood productions) in film consumption echo in the understanding of the position of European film. The European Union - and on a minor scale, the Council of Europe-for decades has responded by supporting European film distribution, providing funds for festivals that promote European content and aiding in finding an audience through the screening of non-national European films in first-run cinemas (European Commission 2017). European film is in many ways seen as the opposite of American film 
productions, if not in market share, then at least in (artistic) quality (Elsaesser 2005). This artistic quality is frequently attributed to the auteurs of European cinema: film directors with distinct styles that range from avant-garde rebellion against Hollywood to the more recent incorporation of references to Hollywood film tradition (Elsaesser 2005 [1994]). Most importantly, the auteurs of European cinema are considered to express themselves, rather than addressing an audience. As such, (European) film becomes a form of art that seeks innovation, instead of being a commercial enterprise (cf. Kersten and Verboord 2014).

This discursive dichotomy between commercial Hollywood and artistic Europe is on many levels artificial; both historically and in the contemporary landscape, European national cinemas have equally produced and continue to produce popular, mainstream, non-auteur films (Dyer and Vincendeau 1992; Bergfelder 2005). In an effort to theorize European cinema, going beyond the study of cinemas in Europe, Bergfelder (2005) concludes that (1) European film is liminal and marginal, (2) it is pan-European in its production and (3) the uniformity of the media product is compromised in its (European) distribution through dubbing and subtitling. That means that European film can indeed be labeled as such, but is strongly contextualized in how and where it is consumed. Audience research among young people in Flanders for instance, where foreign language films are subtitled, underscores this point in that the Flemish strongly disapprove of films that are not in (American) English or, second best, in their native Dutch (Meers 2004, 2002).

Another implication is the curious position of national film in Europe, for it is simultaneously national and European (Van Gorp 2010). Higson finds a solution in emphasizing the relevance of the context of consumption: "(...) a shift away from the analysis of film texts as vehicles for the articulation of nationalist sentiment and the interpellation of the implied national spectator, to an analysis of how actual audiences construct their cultural identity in relation to the various products of the national and international film and television industries, and the conditions under which this is achieved" (Higson 1989: 65). In other words, an analysis of (inter)national media products should take into account their national audiences. The usefulness of the concept of the "national" has been questioned by Higson (2002) arguing that multiple identities exist beyond and within the borders of the nation state. Diasporic film consumption is a case in point here (cf. Vandevelde et al. 2011). As such, the concept of national film can be both too limited or not limited enough (Schlesinger 2002).

\subsection{Hierarchy in Screens: A Matter of Size}

Next to the variability in the origin of the films, the survey also goes into the issue of how audiences watch them. There is a wide body of the literature on the increasing number of screens_-large, small and smaller-on which movies can be watched and consumed. This literature goes back to differences between screening and watching films in the film venue and on television, with Sontag, for instance, declaring the decay of cinema if not watched on a silver screen: "to see a great film only on television isn't 
to have really seen that film. It's not only a question of the dimensions of the image: the disparity between a larger-than-you image in the theater and the little image on the box at home" (Sontag 1996: 1). Others are less deterministic, but stress the importance of screen size. Ellis (1991), for instance, demarcates between screen-related experiences with film. In a rather elitist approach, he argues that watching film on television is a mere pastime activity, whereas watching film in the cinema is a ritual. The latter includes the act of going there, watching collectively, being anonymous in the dark and attentively consuming a film. Others nuance this demarcation: While there are differences in watching film in the cinema and on television, the latter includes as many (social) conventions as the former (Silverstone 1994; Meers and Biltereyst 2012; Greer and Ferguson 2015). Emphasizing that the experience of film will vary in accordance with the size of the screen, Belton concludes that "we must begin to explore the differences among the experiences we have with images and sounds on those screens" (Belton 2014: 470). This chapter translates these experiences into audience practices in analyzing what content is accessed on what screen.

In the contemporary media landscape, there are many possibilities to access one's preferred media content, beyond the traditional screens of the cinema and television. Especially, devices connected to the Internet allow for access to an unlimited number of films. Tryon (2012) conceptualizes these new possibilities under the umbrella of mobile audiences, echoing Jenkins' (2006) "migratory audiences." We can distinguish three ideal types of audience mobility. First, platform mobility means that content can be accessed on a range of devices. Second, with spatial mobility, one can watch wherever. And lastly, one can watch whenever, which Tryon (2012) dubs temporal mobility. He grounds his analysis in advertisements, which he finds to promote personal (and by implication solitary) viewing. The individuality that comes with these viewing practices implies a more personalized media consumption experience.

Atkinson (2014), who argues for an engaged contemporary audience, also argues that today's film extends beyond the cinema screen. She underlines her argument by analyzing films specifically designed to be watched on a tablet, such as The Silver Goat (2012). Likewise, Odin includes the small screen as cinematic, contrary to what one might expect: "at first sight, everything seems to be the opposite of watching a film in a cinema when we watch on a mobile: small screen, poor sound and picture quality, unenclosed environment, mobility and the subordination of the viewing subject to external circumstances" (Odin 2012: 156). However, Odin (2012) concludes the opposite. With the smartphone, he argues we gain a valuable means of both making and watching film. As such, it allows for more involved film audiences.

However, in the early 2000s, the big screen also finds its way into people's homes. One of the most extensive studies on "home cinema cultures" is conducted by Klinger (2006), who introduces the concept of "new media aristocrats" to describe how technophiles create immersive film settings in the home, including big screens and extensive sound systems. Like Tryon (2012), Klinger (2006) grounds her analysis in commercials for home appliances. However, she does remark that the consumption of this type of technology implies a high (masculine) status. This makes it more of a well-esteemed exception worthy of aspiration, than an everyday means of home film consumption. In doing so, Klinger (2006) makes a crucial distinction between 
the possibilities for consumption (big screens and extensive sound systems) and the consumption practices themselves (few aspire to have these technologies).

The relevance of this distinction echoes in the few social scientific studies on audience practices across different devices. Macek and Zahrádka (2016), for example, find that the vast majority of Czech audiences watch film on linear television broadcast $(90.4 \%)$. The younger the audiences, the more likely they are to also use other devices to watch film. However, these devices do not substitute watching film on television. Among respondents aged 18-29, 79.6\% watch film via linear television broadcast, and $68.1 \%$ also watch films on other devices. A study by Greer and Ferguson (2015) yields similar results among American college students aged 18-22. Watching television on a tablet does not replace watching television on a television set. Rather, they find a positive correlation between the uses of both technologies. In other words, tablet and television set complement each other. The results are slightly different for Netflix; watching films via this streaming service is strongly associated with a tablet. ${ }^{3}$

In summary, we identify merits to either screen size in watching film. Traditionally, the bigger screens are considered to be better and most suitable for watching film (Ellis 1991; Klinger 2006; Belton 2014). At the same time, contemporary film content is designed for a plethora of screens (Atkinson 2014; Odin 2012), including those that facilitate mobility and content selection (Tryon 2012; Jenkins 2006). In analyzing whether today's preferences for different types of screens exist in the traditional screen hierarchies and whether these are related to film origin, we analyze individualized and mobile media consumption.

\subsection{Methods}

In search of remaining structures in contemporary film practices and preferences, we conducted a large-scale survey among a stratified sample of 1015 Flemish students in the two final years of their high school education (aged 16-18). The questionnaire included questions on where, how and with whom films were watched, as well as questions on film and screen preferences (Veenstra et al. 2017). ${ }^{4}$ All surveys were digitalized using OMR software and analyzed using SPSS. Although we will present some general results from this survey, this chapter moves beyond the more traditional measures of screen use and content appreciation by focusing upon audience's engagement with a selection of concrete film titles.

\footnotetext{
${ }^{3}$ This may have changed since 2011, as Netflix became (more often) accessible via television sets.

${ }^{4}$ In the first half of 2015, the researcher visited 33 schools in Flanders, to supervise the completion of the questionnaires. Three more schools supervised completion themselves. The stratified sample is constructed through type and level of education. Participating schools were selected randomly. All students completed the 45-min questionnaire during school hours. Questionnaires have been digitalized using OMR software, and statistical analyses have been conducted using SPSS software.
} 
Table 13.1 Selected film titles

\begin{tabular}{l|l|l}
\hline Origin & More action-driven film genres & Less action-driven film genres \\
\hline \multirow{4}{*}{ Hollywood } & Interstellar (2014) & The Wolf of Wall Street (2013) \\
\cline { 2 - 3 } & $\begin{array}{l}\text { Sherlock Holmes: A Game of Shadows } \\
(2011)\end{array}$ & Frozen (2013) \\
\cline { 2 - 3 } & Django Unchained (2012) & The Fault in Our Stars (2014) \\
\hline \multirow{5}{*}{ Flemish } & W.-Witse de Film (2014) & The Broken Circle Breakdown (2012) \\
\cline { 2 - 3 } & Rundskop (2011) & F. C. De Kampioenen (2013) \\
\cline { 2 - 3 } & Crimi Clowns: De Movie (2013) & Zot van A. (2010) \\
\hline \multirow{5}{*}{ European } & Tinker Tailor Soldier Spy (2011) & La Grande Bellezza (2013) \\
\cline { 2 - 3 } & Melancholia (2011) & The Grand Budapest Hotel (2014) \\
\cline { 2 - 3 } & A Most Wanted Man (2014) & The Intouchables (2011) \\
\hline
\end{tabular}

For each of the three categories of film origins discussed earlier (Hollywood, Flemish film and European film), we selected six film titles. We questioned respondents on whether (1) they knew the films and (2) they had seen the films. If the second question was answered affirmatively, we subsequently asked them to rate the film and to indicate on which screen(s) they had seen it. It was possible to indicate multiple screens, as we intended to include repeat viewings. This list of selected films can be found in Table 13.1. All selected films were released in cinemas across Belgium and date no further back than academic year 2010-2011. This means that the youngest participating students would have been in their first year of high school when the film was released. Titles are selected from those with the highest box office successes, as published by Box Office Mojo. To assure a spread across film genres, we distinguish between the more and less action-driven film genres based on the IMDb genre classification. ${ }^{5}$

The resulting list is tentative; the six films per origin are not selected to analyze film industries. Even less so do the selected nine film titles per type of genre facilitate an analysis of a wide array of [often hybrid, cf. Staiger (2000)] film genres. However, our research does not aim to map film industries, nor film genres. It aims to compare film consumption across origins and screens in search of structures in practices and preferences. For such an analysis, we are confident that the films listed above present a strong and well-spread operationalization between countries of production.

Before moving on to analyzing film consumption within the frameworks of European film, national film and Hollywood film, we present a cluster analysis (Ward's method with a squared Euclidean distance interval). In this analysis, we identify possible clusters in the country of origin in our data. We based the analysis on the evaluation of films from eight different countries (measured on a five-point Likert

\footnotetext{
${ }^{5}$ Less action-driven includes the genres: animation, drama, youth and family, comedy and humor, historical costume, musical and music, romantic film, documentary and biography. More actiondriven includes the genres: action and adventure, detective and mystery, horror, war and disaster, science fiction and fantasy, thriller and crime, western.
} 
Table 13.2 Agglomeration schedule (baseline categories: American film [1], Flemish film [2], Belgian film in French [3], French film [4], British film [5], Spanish film [6], German film [7] and Italian film [8])

\begin{tabular}{l|l|l|l|l|l|l}
\hline \multirow{2}{*}{ Stage } & \multicolumn{2}{|l|}{ Cluster combined } & \multirow{2}{*}{ Coefficients } & \multicolumn{2}{|l|}{ Stage cluster first appears } & \multirow{2}{*}{ Next stage } \\
\cline { 2 - 3 } & Cluster 1 & Cluster 2 & & Cluster 1 & Cluster 2 & \\
\hline 1 & 6 & 8 & 203.500 & 0 & 0 & 3 \\
\hline 2 & 3 & 4 & 503.000 & 0 & 0 & 4 \\
\hline 3 & 6 & 7 & 954.833 & 1 & 0 & 5 \\
\hline 4 & 3 & 6 & 2010.400 & 2 & 3 & 7 \\
\hline 5 & 1 & 5 & 3117.900 & 0 & 0 & 6 \\
\hline 6 & 1 & 2 & 4552.400 & 5 & 0 & 7 \\
\hline 7 & 1 & 3 & $10,820.000$ & 6 & 4 & 0 \\
\hline
\end{tabular}

scale with neutral included in the middle; the ratings can be found in Table 13.4). We operationalized European film by including the five largest European nations: France, Great Britain, Spain, Germany and Italy. ${ }^{6}$ Belgian film in French was added to compare within the country. The cluster analysis points to a European film cluster that includes Belgian films in French, French films, Italian films, Spanish films and German films. A second cluster consists of Flemish films (or Belgian films in Dutch, if you will). Lastly, we identify a cluster that consists of American (or Hollywood) and British film, in other words: films in English. The findings are summarized in Table 13.2.

This analysis illustrates two things: (1) a first indication that structures remain in film consumption among youth in Flanders and (2) that it is a fruitful exercise to continue our analysis within the framework of European film, national (or Flemish) film and Hollywood film (which can be extended to films in British or American English). But before exploring preferences and practices within this framework, we will first present some general results on film-watching practices and preferences.

\subsection{Measures of Film Consumption: Watching Film Today}

In general, the survey underlined that watching film remains very popular among youth in Flanders. Nine out of ten respondents saw at least one film in the seven days prior to the questionnaire. Two-thirds saw two or more films. The activity is also thoroughly enjoyed: $84 \%$ of youth in Flanders like watching film, $13 \%$ are neutral, and only $3 \%$ do not like the activity. In similar fashion, $77 \%$ of youth like going to the cinema, $5 \%$ do not, and $18 \%$ are neutral. The silver screen is most popular for watching films; a little over half $(52 \%)$ of all youth prefer the cinema over all other means to watch film. Television comes in second, at almost one-third (31\%) of the

\footnotetext{
${ }^{6}$ The Brexit referendum had not yet taken place at the time of the questionnaire design.
} 
votes. Of the new screens, only the PC/laptop is somewhat popular, with a preference rate of $12 \%$. The projector $(3 \%)$, tablet $(1 \%)$ and smartphone $(1 \%)$ come in last. This means that traditional screens remain most popular in accessing film.

As expected, preferences do not necessarily equate to practices. In a measure of the latter, we find that most youth watch film on television, followed by cinema. So, again, traditional screens prevail for film consumption. This time however, they switch position. In addition, we measured the way film content was accessed on each screen, taking the complexity of the contemporary media landscape into account. There are nine ways in which film can be accessed: (1) linear broadcast on television (also accessible on other screens via apps), (2) recorded from television, (3) additional film subscriptions (extra theme channels via digital television), (4) separate film subscriptions (e.g., Netflix), (5) pay per stream, (6) unpaid streaming, (7) rented DVD/Blu-ray, (8) owned DVD/Blu-ray and (9) digitally stored film. An "other" category was offered, but rarely completed. The top three ways of accessing film via different screens are summarized in Table 13.3. Here, another more traditional pattern in watching film surfaces.

Film watched on television is mostly consumed via linear access, sometimes delayed, or on owned DVD/Blu-ray disk — as also found by Macek and Zahrádka (2016) in the Czech Republic. This finding challenges the agency ascribed to contemporary audiences (Tryon 2012); most films consumed by youth in Flanders are found within the structural constraints of broadcast schedules and cinema programs. This also means that film consumption, despite the many possibilities for access, remains structured through, for example, windowing (Nelson 2014). There is one exception: the PC/laptop. While not used as frequently and by as many young people, it is a popular means of accessing film. Mostly used for individually selected unpaid streams, it is the only screen that points to the active and migratory audiences described by Jenkins (2006). The remaining smaller screens are unpopular for watching film.

Only $14 \%$ of youngsters in Flanders indicated they have access to a projector at home. This means that home cinema cultures mimicking cinema-like technology are the exception, rather than the rule (Klinger 2006). In practice, the projector also proves unpopular-much less popular than the cinema. Thus, when large screens are concerned, the one that is limited in content, time and place is more popular than the one that facilitates choice in all of these components of watching film. Moreover, film-watching practices on the projector most often concern DVD/Blu-ray. That is, selection takes place from the limited resource of purchased disks. Consequently, film consumption on large screens, like linear film consumption on television, takes place within a structure of limited supply. Again, this contradicts the understanding of contemporary audiences as mobile and underlines the importance of understanding the structures that guide media consumption.

A second conventional measure of media consumption is preference in type of film. In this chapter, we explore hierarchies in film consumption through preferences in origin. When asked to complete top three lists of favorite films (which, respectively, were Fast \& Furious, The Hunger Games and Harry Potter), actors/actresses 
Table 13.3 Most frequent ways of accessing film (per screen, largest observations in bold)

\begin{tabular}{|c|c|c|c|c|c|c|c|}
\hline Screen & $\begin{array}{l}\text { Way of } \\
\text { watching }\end{array}$ & $\begin{array}{l}\text { Every } \\
\text { day (\%) }\end{array}$ & $\begin{array}{l}\text { Every } \\
\text { other } \\
\text { day }(\%)\end{array}$ & $\begin{array}{l}\text { Every } \\
\text { week } \\
(\%)\end{array}$ & $\begin{array}{l}\text { Every } \\
\text { month } \\
(\%)\end{array}$ & $\begin{array}{l}\text { Every } \\
\text { year }(\%)\end{array}$ & $\begin{array}{l}\text { Never } \\
(\%)\end{array}$ \\
\hline Cinema & N/A & 0 & 1 & 2 & 49 & 45 & 3 \\
\hline \multirow[t]{3}{*}{ Television } & Linear & 5 & 7 & 41 & 30 & 10 & 7 \\
\hline & Recorded & 3 & 8 & 39 & 30 & 8 & 13 \\
\hline & $\begin{array}{l}\text { Owned } \\
\text { disk }\end{array}$ & 1 & 2 & 7 & 22 & 32 & 37 \\
\hline \multirow[t]{3}{*}{ PC/laptop } & $\begin{array}{l}\text { Unpaid } \\
\text { stream }\end{array}$ & 3 & 7 & 19 & 19 & 11 & 41 \\
\hline & $\begin{array}{l}\text { Owned } \\
\text { disk }\end{array}$ & 0 & 1 & 4 & 13 & 21 & 60 \\
\hline & $\begin{array}{l}\text { Digitally } \\
\text { stored }\end{array}$ & 1 & 2 & 8 & 2 & 15 & 62 \\
\hline \multirow[t]{3}{*}{ Tablet } & Linear & 1 & 1 & 3 & 5 & 5 & 84 \\
\hline & $\begin{array}{l}\text { Unpaid } \\
\text { stream }\end{array}$ & 1 & 1 & 3 & 6 & 5 & 84 \\
\hline & Recorded & 1 & 1 & 3 & 5 & 4 & 87 \\
\hline \multirow[t]{3}{*}{ Smartphone } & $\begin{array}{l}\text { Unpaid } \\
\text { stream }\end{array}$ & 1 & 2 & 3 & 5 & 4 & 86 \\
\hline & Linear & 1 & 1 & 2 & 4 & 4 & 89 \\
\hline & $\begin{array}{l}\text { Digitally } \\
\text { stored }\end{array}$ & 0 & 1 & 2 & 2 & 6 & 90 \\
\hline \multirow[t]{3}{*}{ Projector } & $\begin{array}{l}\text { Owned } \\
\text { disk }\end{array}$ & 0 & 0 & 1 & 7 & 25 & 67 \\
\hline & $\begin{array}{l}\text { Digitally } \\
\text { stored }\end{array}$ & 1 & 0 & 1 & 5 & 11 & 82 \\
\hline & $\begin{array}{l}\text { Unpaid } \\
\text { stream }\end{array}$ & 0 & 1 & 1 & 3 & 11 & 85 \\
\hline
\end{tabular}

(found to be Johnny Depp, Vin Diesel and Leonardo DiCaprio) ${ }^{7}$ and directors (quite unanimously Steven Spielberg, Quentin Tarantino and Peter Jackson), the outcome among youth in Flanders overwhelmingly points to (the men in) Hollywood. This finding is in line with the diverse appreciation for film from various countries in Table 13.4.

Thus, Hollywood dominates in taste preferences among youth in Flanders. Yet while Hollywood might be most popular, it is not the only film country evaluated positively. Both British film (like Hollywood film in English) and Flemish film (in Dutch) score above average with a little over three points out of five. As such, Hollywood is indeed a central point of reference (Scott 2005). But it might not be as

\footnotetext{
${ }^{7}$ Preferences that remind the first author of her time in high school 15 years ago; posters of the same men might have been found in her room at the time.
} 
Table 13.4 Evaluation of film origin

\begin{tabular}{l|l|l}
\hline \multicolumn{2}{l|}{ Origin } & Mean (SD) \\
\hline Hollywood & American & $4.27(0.895)$ \\
\hline \multirow{3}{*}{ Belgian } & Flemish & $3.14(1.103)$ \\
\cline { 2 - 3 } & Walloon/Brussels & $2.07(1.006)$ \\
\cline { 2 - 3 } & British & $3.31(1.138)$ \\
\cline { 2 - 3 } & French & $2.17(1.099)$ \\
\cline { 2 - 3 } & Italian & $1.87(0.975)$ \\
\cline { 2 - 3 } & Spanish & $1.86(0.939)$ \\
\cline { 2 - 3 } & German & $1.81(0.934)$ \\
\hline
\end{tabular}

The question was how much one enjoyed watching films from a variety of originating countries from "very much so" to "not at all" on a five-point scale. The category neutral was included in the middle

hegemonic as some authors argue (Fu 2012; Fu and Govindaraju 2010). The local Flemish film proves fairly popular, especially in comparison with Belgian films in French. These are rated similar to French films. This underlines the importance of context in European film consumption (Bergfelder 2005; Hjort and Petrie 2007; Higson 2002). For Flanders, the language of film will prove significant: Films in the mother tongue are favored over (non-English) foreign language films (Meers 2004). Following this analysis, we can conclude that European film remains as (un)popular as it was at the turn of the millennium (Meers 2002) — despite efforts by the European Union to popularize its films (European Commission 2017). There is one exception: British film; in sitting comfortably in the same cluster as Hollywood, its popularity underlines the importance of language in film. However, it is not as popular as Hollywood film. As such, like Flemish film, it floats between the popular Hollywood film and the unpopular European film. The final cluster consists solely of Flemish—or national-film.

To summarize, in an age of unlimited access, film consumption preferences remain shaped along traditional hierarchical lines of origin: (1) Hollywood (which can be extended to films in British English), (2) Flemish (or "national") and (3) European film. As was the case for the variety of screens, there are important implications along the lines of political economy: If audiences stay put, rather than migrating (Jenkins 2006), media industries remain crucial in shaping media consumption (Holt and Sanson 2014). Audiences, thus, do not select just any screen or just any film. Rather, they consume film in patterns we recognize from an offline preconvergence culture era; like Greer and Ferguson (2015), we find existing media repertoires structure consumption. That brings us to the final section of this chapter: Can we find similar structuring patterns in media consumption when we combine content (origin) and screen-two aspects that are found to facilitate contemporary audience agency? 


\subsection{Films on Screens: Detailed Measurements of Film Consumption}

In a detailed measurement of film knowledge, consumption and appreciation, our selection of eighteen film titles confirms the patterns we found earlier: Hollywood film is evaluated best, European film is evaluated worst, and cinema and television screens are most popular for watching films, followed by the PC/laptop at a distance-see Table 13.5. However, preferences somewhat diverge from practices. While Hollywood is appreciated slightly more with grades around 4 out of 5, Flemish film is as well known as the most popular titles known by the majority of students, viewed as often as Hollywood film. European film is least known and rarely viewed, sometimes by as few as 10-20 students. And when European film is viewed, ratings are low - though higher than the overall ratings for European film in the former section. The Intouchables (2011) is the exception here. This film is similar to Hollywood films in its popularity, as it is well known (by 74\% of all students), well viewed (by $52 \%$ of all students) and highly rated with a 4.1 .

To further explore the patterns between content and screen, we focus on the various screens that respondents indicated they had seen the films on. ${ }^{8}$ This analysis further nuances our understanding of film consumption practices. We see that Hollywood film is consumed in the cinema, on television and on the PC/laptop. In short, it is popular on all common screens to watch film. The high number of students that have seen the Hollywood titles in the cinema, especially Interstellar (57\%) and The Fault in Our Stars (56\%), is exceptional. The only Flemish film that approaches this share in cinema attendance is $F$. C. De Kampioenen (57\%). Generally, Flemish films are watched on television; the remaining film titles display audience shares between 68 and $84 \%$. Neither of the titles in national film are accessed often via PC/laptop, tablet or smartphone.

The analysis for European film is a bit more complex, because only a few students saw the films listed. Nonetheless, we see that the PC/laptop is a popular way to access these films and more common than via a television screen and far more popular than the silver screen, for example with A Most Wanted Man and The Grand Budapest Hotel. This finding might indicate that less accessible content is indeed found by active audiences through online means. However, it concerns only very small audiences: Between 2 and $9 \%$ of the young people saw one of the European films. The exception is, again, The Intouchables (2011). With an audience of over half of high school students in Flanders (52\%), it is comparable to Hollywood films when it comes to screen choice. Also, it is the only film regularly watched on a projector screen (33\%). A likely explanation is that it is watched in school; the film was often mentioned to be screened in French class.

Thus, Hollywood film is clearly deemed suitable for all screens and shows the strongest connection to the cinema, Flemish film is predominantly watched on television, and European film is mainly accessed via the PC/laptop, followed by television.

\footnotetext{
${ }^{8}$ For this analysis, only the entries of the respondents that answered both questions are included.
} 
13 Structured Film-Viewing Preferences and Practices ...

\begin{tabular}{|c|c|c|c|c|c|c|c|c|c|c|c|c|c|c|c|c|c|c|}
\hline 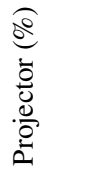 & 0 & $m$ & $r$ & $r$ & $r$ & $m$ & 0 & in & in & $m$ & $N$ & $N$ & 0 & 0 & 0 & 0 & $m$ & 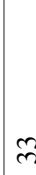 \\
\hline 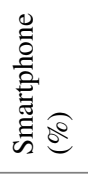 & $N$ & 0 & 0 & $\sim$ & - & - & 0 & 0 & - & 0 & - & 0 & 0 & 0 & 0 & 0 & 0 & 0 \\
\hline$\frac{\widehat{o}}{\frac{0}{0}}$ & $m$ & $N$ & $\nabla$ & $m$ & $m$ & $m$ & 0 & 0 & - & - & - & 0 & 0 & 0 & 0 & 0 & $m$ & - \\
\hline
\end{tabular}

ญ. है के 这 站通

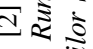
$\div \infty$

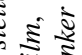
这语 $\Xi \approx \pi$ $\Sigma$ ะ

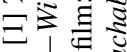

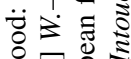
등 产 官家志 近 $\ddot{0} \overline{0}: \overrightarrow{0}$ है छ ฐ

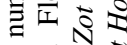
ஈ \begin{tabular}{|l|l|l|l|l|l|l|l|l|l|l|l|l|l|}
\hline & & & & & & & & & & & & & \\
\end{tabular}

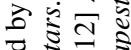
㐘 范 苛. ए.

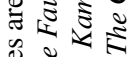

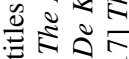

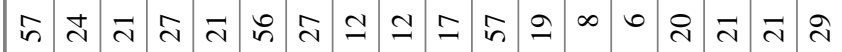
छ曰u วิ

总 Z

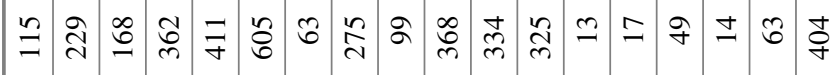
宊

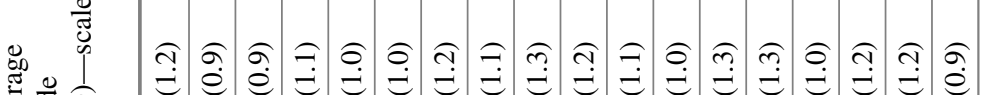

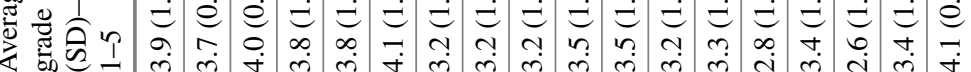

$\ddot{\Xi}$ 品

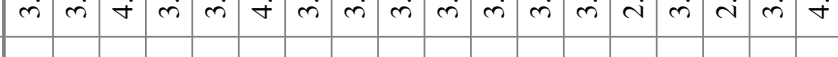

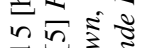


Inherently, the structures that surface contest the personal and individualized media consumption practices as argued by authors such as Jenkins (2006) and Tryon (2012). Moreover, these results illustrate that watching film cannot be analyzed based on a mere choice in content and screen. For more detailed and meaningful results, a combined approach is crucial. The strong hierarchies in screen and origin point toward the continuity of structured media consumption, nuancing or even contradicting discourses on convergence culture and its alleged migratory audiences (Atkinson 2014; Biltereyst and Meers 2011; Couldry 2011; Klinger 2006).

\subsection{Conclusion}

Through a variety of analyses in this chapter, a series of recurring patterns in film consumption appear. We find hierarchies in film consumption for content and screen, respectively: Hollywood and the cinema are most popular among Flemish youngsters. European films and small portable screens are least popular for movie consumption. And hierarchies solidify when measured in a detailed analysis of film titles and filmwatching practices: Highly rated Hollywood films are watched in the cinema, and the less valued Flemish films are watched on television. This is in line with earlier findings from studies conducted before the alleged rise of convergence culture (Meers 2002, 2004).

But while films may be valued differently and consumed on different screens, the frequency in knowledge and consumption is rather similar between Flemish and Hollywood films. This underlines the cultural specificity and local anchorage of the national film industries and their audiences (Hjort and Petrie 2007): While there may be a highly valued and vast library of Hollywood films available via different platforms, the local Flemish film has a prominent place in the cultural consumption of contemporary young Flemish audiences. As such, film consumption is firmly embedded in the structures of the local culture. This is further confirmed by the lack of popularity of films from other European countries or even Belgian film in French, while Flemish film would be considered "European" in regions outside Flanders (Bergfelder 2005). The geographic location of film consumption therefore matters in film appreciation and should be included in analyses of preferences and practices.

If anything, the patterns and hierarchies analyzed in this chapter underline the (continuing) importance of structure in contemporary film consumption. As such, our results challenge the merits of focusing solely on audience agency, since the subjects of recent studies on audience practices and analyses of possibilities (Tryon 2012) and practices of specialized (fan) communities (Jenkins 2006), which are often taken as exemplary, are far from being common practice among general audiences. Our findings are in line with existing generalizable studies on audience practices (Macek and Zahrádka 2016; Greer and Ferguson 2015). Moreover, they underline the importance of monitoring both the diversity and continuity in (film) audience practices (Couldry 2011), as well as the political-economically informed frameworks within which these practices take place (Biltereyst and Meers 2011). 
Studying detailed audience practices, such as their acquaintance with and appreciation of specific film titles, increases our understanding of the existing hierarchies that frame consumption practices. But further context is needed in exploring hierarchical consumption patterns, both quantitatively and qualitatively, with many questions still to be answered. Why exactly do audiences make the choices they make? What kinds of new technologies and devices will change audiences' preferences and behavior? What are the social, economic, cultural and other barriers for audiences' film and media choices, preferences and practices? We hope our study contributes to a critical understanding of the classical continuum between agency and structure, when dealing with European film audiences in an era of convergence.

\section{References}

Atkinson, S. (2014). Beyond the screen: Emerging cinema and engaging audiences. New York, London: Bloomsburry Academic.

Belgian Federal Government. (2017). Bevolking: Cijfers Bevolking 2010-2016. https://statbel. fgov.be/nl/modules/publications/statistiques/bevolking/bevolking_-_cijfers_bevolking_2010_-_ 2012.jsp. Accessed September 9, 2017.

Belton, J. (2014). If Film is Dead, What is Cinema? Screen, 55(4), 460-470.

Bennett, A., \& Robards, B. (2014). Introduction: Youth, cultural practice and media technologies. In A. Bennett \& B. Robards (Eds.), Mediated youth cultures: The internet, belonging and new cultural configurations (pp. 1-7). Hampshire, New York: Palgrave Macmillan.

Bergfelder, T. (2005). National, transnational or supranational cinema? Rethinking European film studies. Media, Culture \& Society, 27(3), 315-331.

BFI/British Film Institute. (2015). Audiences. London: British Film Institute. https://www.bfi.org. uk/sites/bfi.org.uk/files/downloads/bfi-audiences-2015-11.pdf. Accessed September 9, 2017.

Biltereyst, D., \& Meers, P. (2011). The political economy of audiences. In J. Wasko, G. Murdock, \& H. Sousa (Eds.), The handbook of political economy of communications (pp. 415-435). Malden, MA: Wiley-Blackwell.

Bird, E. S. (2011). Are we all producers now? Convergence and media audience practices. Cultural Studies, 25(4-5), 502-516.

Couldry, N. (2011). More sociology, more culture, more politics. Or, a modest proposal for 'Convergence' studies. Cultural Studies, 25(4-5), 487-501.

Cucco, M. (2009). The promise is great: The blockbuster and the hollywood economy. Media, Culture \& Society, 31(2), 215-230.

Decherney, P. (2013). Hollywood's copyright wars: From Edison to the internet. New York: Columbia University Press.

Dyer, R., \& Vincendeau, G. (1992). Popular European cinema. London: Routledge.

Edge, M. (2011). Convergence after the collapse: The 'Catastrophic' case of Canada. Media, Culture \& Society, 33(8), 1266-1278.

Ellis, J. (1991). Visible fictions: Cinema, television, video. London: Routledge.

Elsaesser, T. (2005). European cinema: Face to face with Hollywood. Amsterdam: Amsterdam University Press.

Elsaesser, T. (2012). The persistence of Hollywood. London: Routledge.

European Commission. (2017). Media overview: Supporting and promoting Europe's audiovisual sector. https://ec.europa.eu/programmes/creative-europe/media_en. Accessed April 12, 2017.

Fu, W. W. (2012). National audience tastes in Hollywood film genres: Cultural distance and linguistic affinity. Communication Research, 40(6), 789-817. 
Fu, W. W., \& Govindaraju, A. (2010). Explaining global box-office tastes in Hollywood films: Homogenization of national audiences' movie selections. Communication Research, 37(2), 215238.

Greer, C. F., Ferguson D. A. (2015). Tablet computers and traditional television (TV) viewing: Is the iPad replacing TV? Convergence: The International Journal of Research into New Media Technologies, 21(2), 244-256.

Hall, S. (2002). Tall revenue features: the genealogy of the modern blockbuster. In S. Neale (Ed.), Genre and contemporary Hollywood (pp. 11-26). London: British Film Institute.

Hay, J., \& Bailey, S. (2002). Cinema and the premises of youth: 'Teen Films' and their sites in the 1980s and 1990s. In S. Neale (Ed.), Genre and contemporary Hollywood (pp. 218-235). London: British Film Institute.

Higson, A. (1989). The concept of national cinema. Screen, 30(4), 36-46.

Higson, A. (2002). The limiting imagination of national cinema. In M. Hjort \& S. Mackenzie (Eds.), Cinema and nation (pp. 63-74). London: Routledge.

Higson, A., \& Maltby, R. (1999). "Film Europe" and "Film America": An introduction. In A. Higson \& R. Maltby (Eds.), "Film Europe" and "Film America": Cinema, commerce and cultural exchange, 1920-1939 (pp. 1-31). Exeter: University of Exeter Press.

Hjort, M., \& Petrie, D. (2007). Introduction. In M. Hjort \& D. Petrie (Eds.), The cinema of small nations (pp. 1-22). Edinburgh: Edinburgh University Press.

Holt, J., \& Sanson, K. (2014). Introduction: Mapping connections. In J. Holt \& K. Sanson (Eds.), Connected viewing: Selling, streaming, \& sharing media in the digital era (pp. 1-16). London: Routledge.

Jenkins, H. (2006). Convergence culture: Where old and new media collide. New York: New York University Press.

Jenkins, H., Ford, S., \& Green, J. (2013). Spreadable media: Creating value and meaning in a networked culture. New York: New York University Press.

Jenkins, H., Ito, M., \& Boyd, D. (2016). Participatory culture in a networked era. Cambridge and Malden: Polity Press

Kersten, A., \& Verboord, M. (2014). Dimensions of conventionality and innovation in film: The cultural classification of blockbusters, award winners, and critics' favourites. Cultural Sociology, $8(1), 3-24$.

Kim, J. (2012). The institutionalization of YouTube: From user-generated content to professionally generated content. Media, Culture \& Society, 34(1), 53-67.

Klinger, B. (2006). Beyond the multiplex: Cinema, new technologies, and the home. Berkeley: University of California Press.

Macek, J., \& Zahrádka, P. (2016). Online piracy and the transformation of the audiences' practices: The case of the Czech Republic. In D. H. Hick \& R. Schmücker (Eds.), The aesthetics and ethics of copying (pp. 335-358). London: Bloomsbury.

Maltby, R. (1999). Sticks, hicks and flaps: Classical Hollywood's generic conception of its audiences. In M. Stokes \& R. Maltby (Eds.), Identifying Hollywood's audiences: Cultural identity and the movies (pp. 23-41). London: British Film Institute Publishing.

Meers, P. (2002). Filmpubliek en (Europese) cinema. Theoretische Verkenning en Survey bij Jongeren in Vlaanderen. Tijdschrift voor Sociologie, 23(3/4), 509-543.

Meers, P. (2004). 'It's the language of film!': Young film audiences on Hollywood and Europe. In R. Maltby \& M. Stokes (Eds.), Hollywood abroad: Audiences and cultural exchange (pp. 158-175). London: British Film Institute Publishing.

Meers, P., \& Biltereyst, D. (2012). Film audiences in perspective: The social practices of cinemagoing. In H. Bilandzic, G. Patriarche, \& P. J. Traudt (Eds.), The social use of media: Cultural and social scientific perspectives on audience research (pp. 123-140). Bristol: Intellect.

Miller, T., Govil, N., McMurria, H., \& Maxwell, R. (2001). Global Hollywood. London: British Film Institute.

Moisander, J., Könkkölä, S., \& Laine, P.-M. (2013). Consumer workers as immaterial labour in the converging media markets: Three value-creation practices. International Journal of Consumer Studies, 37(2), 222-227. 
Nelson, E. (2014). Windows into the digital world: Distributor strategies and consumer choice in an era of connected viewing. In J. Holt \& K. Sanson (Eds.), Connected viewing: Selling, streaming, \& sharing media in the digital era (pp. 62-78). London: Routledge.

Odin, R. (2012). Spectator, film and the mobile phone. In I. Christie (Ed.), Audiences (pp. 155-169). Amsterdam: Amsterdam University Press.

Olsen, S. R. (1999). Hollywood planet: Global media and the competitive advantage of narrative transparency. Mahwah: Lawrence Erlbaum.

Schlesinger, P. (2002). The sociological scope of 'National Cinema.' In M. Hjort \& S. Mackenzie (Eds.), Cinema and nation (pp. 19-31). London: Routledge.

Scott, A. J. (2005). Cinema, culture, globalization. In Hollywood: The place, the industry (pp. 159175). Princeton: Princeton University Press.

Silverstone, R. (1994). Television and everyday life. London: Routledge.

Sontag, S. (1996). The decay of cinema. New York Times Magazine, 25, 60-61.

Staiger, J. (2000). Perverse spectators: The practices of film reception. New York: New York University Press.

Tryon, C. (2012). 'Make any room your TV room': Digital delivery and media mobility. Screen, 53(3), 287-300.

Van Gorp, J. (2010). Wat is Nationaal aan Nationale Cinema? Tijdschrift voor Communicatiewetenschap, 38(1), 49-62.

Vandevelde, I., Smets, K., Meers, P., Winkel, R. V., \& Van Bauwel, S. (2011). Bollywood and Turkish Films in Antwerp (Belgium): Two case studies on diasporic distribution and exhibition. Javnost-The Public, 18(3), 55-70.

Vlaams Audiovisueel Fonds. (2016). VAF/Filmfonds. https://www.vaf.be/over-het-vaf/ vaffilmfonds. Accessed October 25, 2016.

Veenstra, A., Meers, P., \& Biltereyst, D. (2017). Pick, play, produce: Revisiting the concept of participation through a quantitative study of film consumption practices amongst youth in Flanders (Belgium). Tripodos, 40, 73-90.

Willems, G. (2010). A comparative analysis of contemporary film policy in Flanders and Denmark. Tijdschrift Voor Communicatiewetenschap, 38(2), 172-186.

Aleit Veenstra recently received her Ph.D. in communication studies from the University of Antwerp, where she is a member of the Visual and Digital Cultures Research Center (ViDi). She worked on the project Screen(ing) Audiences, focusing on contemporary film audiences. She is the author of articles on popular culture, consumption and film audiences.

Philippe Meers is Professor of film and media studies, the University of Antwerp, where he chairs the Center for Mexican Studies and serves as Deputy Director of the Visual and Digital Cultures Research Center (ViDi). He has published widely on historical and contemporary film culture and audiences. With R. Maltby and D. Biltereyst, he edited Explorations in New Cinema History (2011), Cinema, Audiences and Modernity (2012) and The Routledge Companion to New Cinema History (2019). With I. Ilsaket and D. Biltereyst he is currently co-editing a volume on Cinemagoing in the Arab World.

Daniël Biltereyst is Professor of Film and Media Studies, Ghent University, where he leads the Centre for Cinema and Media Studies (CIMS). He is the author of over 200 essays and the coeditor of several volumes, including Explorations in New Cinema History and Cinema (2011), Cinema, Audiences and Modernity (2012), Silencing Cinema: Film Censorship around the World (2013), Moralizing Cinema (2015) and The Routledge Companion to New Cinema History (2019). He is finalizing Mapping Movie Magazines (2018) and is currently working on Cinemagoing in the Arab World. 
Open Access This chapter is licensed under the terms of the Creative Commons Attribution 4.0 International License (http://creativecommons.org/licenses/by/4.0/), which permits use, sharing, adaptation, distribution and reproduction in any medium or format, as long as you give appropriate credit to the original author(s) and the source, provide a link to the Creative Commons license and indicate if changes were made.

The images or other third party material in this chapter are included in the chapter's Creative Commons license, unless indicated otherwise in a credit line to the material. If material is not included in the chapter's Creative Commons license and your intended use is not permitted by statutory regulation or exceeds the permitted use, you will need to obtain permission directly from the copyright holder.

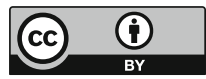

